Euskal ikerketen aldizkaria | Revue d'études basques |

Revista de estudios vascos | Basque studies review

$13 \mid 2009$

Numéro XIII

\title{
Erakusleak berreraikitzen : arazoaren beste alderdi bat
}

Julen Manterola

OpenEdition

Journals

Édition électronique

URL : http://journals.openedition.org/lapurdum/2130

DOI : 10.4000/lapurdum. 2130

ISSN : 1965-0655

Éditeur

IKER

Édition imprimée

Date de publication : 1 février 2009

Pagination : 261-275

ISBN : 978-2-86781-409-X

ISSN : $1273-3830$

Référence électronique

Julen Manterola, "Erakusleak berreraikitzen : arazoaren beste alderdi bat », Lapurdum [Linean],

13 | 2009, Sarean emana----an 15 avril 2013, kontsultatu 19 avril 2019. URL : http://

journals.openedition.org/lapurdum/2130; DOI : 10.4000/lapurdum.2130

Manterola J. | IKER 


\title{
Erakusleak berreraikitzen: arazoaren beste alderdi bat
}

\author{
Julen MANTEROLA \\ $\mathrm{UPV} / \mathrm{EHU}$
}

\section{Laburpena:}

Artikulu honetan euskal erakusleak berreraiki izan direnean maiz aipatu gabeko arazo batez arduratu naiz. Gradu urruneko erakusleen forma berregituratze morfologiko baten ondorio dela proposatuko dut; honela, euskalki artean, testuetan zein gaur egungo ahozko jardunean, aurkitzen ditugun aldaerak (aek vs. ek, oinarrian) ez dira aldaketa fonetiko soilen ondorio, arestian aipatutako berregituratze morfologikoarena baizik. Proposamen honek deklinabidearen diakronia hobeki ulertzen lagunduko gaitu, eta baita azentuazio patroi ezberdinak azaltzen ere; hein berean, kontaktu egoeren zein euskalkien diakroniaren eztabaida ere ukituko du proposamenak.

\section{Abstract:}

This article addresses a problem that has not been too often raised when reconstructing Basque demonstratives. I will propose that distal plural demonstratives underwent a morphological restructuring; thus, the dialectal variation we find across texts and nowadays speech (basically aek vs. ek) is due not to phonetic changes, but to the aforesaid morphological reorganizing of the demonstratives. This proposal will be useful for a better understanding of the diachrony of declension, for a better explanation of different accentuation patterns, as well as diachronic dialectology and contact issues.

Gako-hitzak: Erakusleak, berregituratze morfologikoa, deklinabidea, kontaktua, dialektologia diakronikoa.

Key-words:Demonstratives, morphological restructuring, declension, contact, diachronic dialectology.

1. Lan hau ez zen posible izango Eusko Jaurlaritzak doktoreak prestatzeko duen programari esker izan ez balitz. 2008ko abenduan Baionan Aldaketak, aldaerak, bariazioak euskaran eta euskal testugintzan mintegia antolatu duten Iker taldeko kideei eskerra zor diet; bertan izandako entzuleei ere arreta eta galderak eskertu nahi dizkiet. 2009ko urtarrilaren 19an Gasteizko Letren fakultatean egindako "etxe-barneko" aurkezpenean ere lantxo honetako zenbait kontu aipatu nuen: bertan izan ziren Borja Ariztimuño, Ricardo Gómez, Joseba Lakarra, Ander Martínez, Koldo Ulibarri eta Blanca Urgell ere eskertu beharrean nago. Céline Mounole bera ere ezinbestean eskertu beharrekoa dut. 


\section{Sarrera}

Lan honek oso helburu ttiki eta zehatza du: hirugarren graduko erakusle pluralen berreraiketa partzial bat eskaintzea. Berreraiketa saio honetan, gainera, nik proposatzen dudan hipotesi "berria" baino, inportanteagoa ikusten dut hipotesi tradizionalaren zenbait hutsune salatzeko egiten den ahalegina. Hartara, eskainiko dudan hipotesi berriaren proposamenarena baino, nahiago nuke lan honek hipotesi zaharrak berriro begiratzearen osasungarria aldarrikatzeko balio izatea.

Sarreran ari naizenez, zilegi zait izenburuaren gaineko azalpena ematea: arazoaren "beste" alderdi batez ariko omen naiz, baina horretarako irakurleari "beste" hori zerekiko den agertu beharko diot lehenago. Euskararen diakroniaren gaineko azterketen historian, inoiz erakusleek arreta erakarri izan dutenean, haiei lan monografikoak eskainiz, esango nuke argumentazio nagusia galdera baten jiran antolatu dela, hots, erakusle sistema osoaren auzian; egun euskal erakusle sistema hiru gradukoa da, latinekoaren (hic, iste, ille) edo gaztelaniakoaren (este, ese, aquel) antzera. Izan da sistema hau garai batean ez hirukoa, baizik bikoa izan zela aldarrikatu duenik (Azkue 19051906: 1-2, Irigoyen 1978, 1981), eta baita halako berreraiketaren beharra ikusten ez duenik ere (Michelena 1979). Eztabaidaren laburpen atsegin bat Azkarate eta Altunaren lanean (2001: 20-40) aurki daiteke.

Ez naiz, baina, gai horretaz arituko eta ez dut, gainera, erakusleen berreraiketa osorik eskainiko; horregatik arestian aipatutako berreraiketaren partziala. Erakusle sistemaren gai zabalaren ordez bigarren mailako arazoa dirudien auzi batez arituko naiz: hirugarren graduko erakusle pluralek hasieran duten bokalaz arituko naiz. Erakusle horiek bi aldaera nagusi dituzte: aek bezalakoak, eta (h)ek bezalakoak. Hasperenaren gorabeherak eta aldaeren banaketa dialektala oraingoz alde batera utzita, bataren ala bestearen aldeko hautua egin beharko du diakronistak, zaharragoa zein den erabaki nahian. Orain artekoan, aek bezalako bi bokaleko formen alde egin izan da aldaera zaharrena zein den erabakitzeko tenorean; nik hemen hautu horrek dituen arazoak agerian utzi nahi izango ditut, eta, kritika horren bidetik, bestelako aukerak bilatzea zilegi dela aldarrikatuko. Hek bezalako formen antzinatasuna izango da gaurko eta hemengo aukeraren aldarria.

Lana honela antolatuko dut: lehendabiziko atalean hipotesi tradizionalaren arazoak zerrendatzen saiatuko naiz, 5 puntutan; bigarren atalean hipotesi berri bat plazaratuko dut, bere aldeko eta aurkakoak zein izan daitezkeen iradokiz; hirugarren atalean hipotesi berriak ikerketari eskaintzen dizkion bideen berri ematen saiatuko naiz. Azken atalean, laugarrenean, gaiarekin lotuak diren bestelako ideiak emango ditut, nahasian, lan honen behin-behinekotasuna salatuko dutenak.

\section{Hipotesi tradizionala. Arazoak}

Gorago aipatu bezala, auzi ttiki honetan, (h)aek eta hek bezalako formen artean zaharrena aukeratu nahi dugun honetan, hipotesi tradizionalak dio (h)aek, (h)aen... formak, bi bokal hiatoan dituztenak, direla zaharrenak. Auzi ttikia diot, baina inplikazio zabalekoa, agerian utziko dudan bezala. Hipotesi tradizionalak forma hauek guztiak ikusten ditu euskalkietan zehar: aek, hek, heiek, haiek...; hipotesi horren esanetan aldaera hauek fonetikoak dira, funtsean, eta hasierako *haek forma proposatuta, beste guztiak ere azaldu daitezke, bilakabide fonetikoetan oso gastu apala eginez. Hala esaten digute Altunak eta Azkaratek (2003: 18):

Pluraleko formez den bezanbatean, euskalkirik gehienetan, jakina den bezala, singularreko absolutiboan oinarritzen dira eta horri gehitzen -ek plural marka: hau / hauek; hori / horiek; ha (hura) / haek > haiek ( $>$ heiek > hek). 
Egiari zor, gauza gehiago ere esaten dute autoreek aipu horretan. Beherago itzuliko gara horretara. Aipu honetan emandako bilakaeren argitara (haek $>$ haiek $>$ heiek $>$ hek ${ }^{2}$ ) ageri da, bestalde, zein den hipotesi tradizionalaren ${ }^{3}$ funtsa: materia foniko gehiago dutenak dira forma zaharrenak.

Zein dira, baina, hipotesi tradizional hau sostengatzeko argudioak? Beldur naiz ez ote den, nagusia, aski azalpen azalekoa, ez bada zirkularra: halako aldaera dialektal zenbait dugu (aek, heiek,...), eta beraz, haek formatik abiarazten dugu denen azalpena; azalpen fonetikoa aldaera dialektalak esplikatzeko eskaintzen da, baina era berean aldaera dialektalen arazoa, azalpenak berak hala erabakita, auzi fonetiko hutsera mugatzen da. Azalpenak berak eragindako xinpletasuna litzateke, hartara, ez datuek beraiek, begirada zorrotzago baten pean, benetan eskaintzen dutena. Ez dira, hala uste dut, datu horiek testuinguru orokorrago baten begiradapean ezarri.

Lan honetan aipatu berri dudan kontua argudiatzen saiatuko naiz, eta erakusten hipotesi "tradizional" honen kamustasuna. Zerrendan emango ditut nire ustez hipotesi honek azaldu gabe uzten dituen bestelako kontuak; egia da, aitor dezadan deus baino lehen, aldaerak bilakabide fonetikoz azaltzeak izan lezakeela -izan beharko lukeela, noski- bere tokia edozein hipotesi alternatibotan. Hemen azalduko ditudanen ondoren, ordea, ezin istorio osoa horretara mugatu. Has gaitezen banan-banan:

a) Hirugarren graduko erakusle pluraletan bilakabide fonetiko hau omen duten euskalkietan, ba al dugu erakusleez kanpoko adibiderik? Hots, haek > hek gertatu omen den hizkeretan, ekialdekoetan alegia, aurkitzen al dugu -ae- > -e- bilakabide fonetikoaren zantzurik? Jakina, galdera hau estu lotua dago gure metodoan "bilakabide fonetikoen itsutasuna" deitzen dugun hatsarre horrekin: erakusleetan gertatzen den fenomeno fonetikoa beste nonbait ere aurkitzea espero dugu horren arabera. Mitxelenak badakartza (1961[1990: 117]) Leizarragaren gizerhaile baina baita "meridional" asteme ere (bietan -ae->-e-); biak eremu dialektal ezberdinekoak, erakusleetan forma ezberdinak dituztenak. Ez naiz ni, seguru aski, egokiena horrelako galdera zehatzari erantzuteko; horretaz aritzeko dialektologo eta fonetikariak finago ibiliko dira. Hortaz, esplizituki erantzun gabe utziko dut galdera hori.

Gogoetarako adibidetxo bat ekarri nahi nuke, dena den: adizkiei -(e)la eta -(e)n atzizkiak gehitzean dan/dala eta den/dela formak ditugu (de Rijk 1981: 95, Michelena 1961[1990: 117]). Onartu nahi badugu forma hauen oinarrian *daen eta *daela daudela, hortxe ditugu gure erakusleetan ageri zaizkigun bokal bilkuren antzekoak. Ez nuke ziurtzat emango, hala ere, adizki hauetan dugun bilakaera eta erakusleena erabat parekagarriak direla: adizkietan, bi forma horiekin euskal eremu osoa estaltzen dugu, erakusleek hainbat forma ezberdinen arteko aukera eskaintzen duten bitartean. Eta hizkera berean, hortaz, erakusle eta adizkietan bilakaera ezberdinak aurki ditzakegu. Ezin ahantz, halaber, bateko eta besteko hiatoak garai ezberdinetakoak izan daitezkeela. Honek guztiak, nola ez, halako formen azterketa xehekatua eskatzen du, hizkeraz hizkerakoa, eta morfemaz morfemakoa, bilakaera fonetiko hauen kronologia ezartzen lagunduko diguna. Egin gabeko lana dut eta dugu honako hau, baina ausartuko naiz esaten auzia fonetika hutsezko kontuetatik haratago ere badoala.

2. Kasu honetan, dena den, hek bezalako zerbait azaltzeko zentzuzkoagoa ikusiko nuke haek $>$ heek $>$ hek bilakabidea. Baina tira, ez dut hemengo lana hipotesi horren xehetasun fonetikoak azaltzearena.

3. Tradizional deitzen dut, baina egia esan idatzirik ez dut maiz ikusi, inoiz ikusi badut; Azkueren Morfologian ez dut honen gaineko aipamenik aurkitu, eta Mitxelenaren zein Irigoienen aipurik ere ez dut bilduta. Esan dezadan, bederen, euskalarien artean normalean onartzen den irtenbidea dela, idatziz ez bada, ahoz. 
b) Hipotesi tradizional honen arabera, halako bokal bilkurak zenbateraino dira antzinako? Argi bereiz daitezkeen morfema ezberdinen talka alde batera utzita, susmoa dut -ae- bokal bilkura ez dela oso arrunta jatorrizko lexema edo morfemetan, ez ekialdeko hizkeretan, ez mendebaldekoetan ere. Aurreko a) puntuan adierazi dugu, berorren bilakaera erakusleetatik landa ere aztertu beharko genukeela, ikusteko bilakabide fonetiko "itsuak" denetan berdin jokatzen ote zuen; baina gauzak honela, seguru aski, bokal talka horiek zergatik gertatu diren aztertzera joko genuke segidan. Mitxelenak berak (1961[1990: 109-123]), hiatoak aztertzen dituenean, antzeko zerbait egiten $\mathrm{du}$, eta hiatoak duten sorburuaren arabera sailkatzen ditu: artikuluaren eransketatik datozenak, *gaztana bezalakoen bilakabidean aurki daitezkeenak (*gaztana>*gaztaa>gaztae>gaztai)...

Puntu honetan esandakoaren arabera, hortaz, hiatoan diren bokal bilkura horien antzinatasuna bera, bere balizko osaera morfologikoarekin batera, aztertu beharko genuke. Bat-bateko begirada egin, eta ikus daitekeena zera da, hek bezalako formak Tartasen lanetan bezala Urruñako 1680 urteko agirietan ere (Múgica 1908) agertzen direla, baina baita gaur egungo Malerrekako Oiz herriko hizkeran ere; adibide baterako ikus eta entzun ahotsak.com (2007). Eremu zabal xamarra, beraz: formaren antzinatasunaren erakusgarri, ala besterik gabe fonetismo jakin baten hedadura zabalaren ondorio? Azken aukera honi segitu nahi izanez gero, aurreko a) atalean proposatutako galderetara itzuli beharra, nolanahi ere.

Laburbilduz, edo kontua zeharkako beste ikuspegi baten pean ezarriz, pentsa liteke maila morfologikoko bi elementuren elkartzeren bat edo gertatu dela hirugarren graduko erakusleetan; halaxe iradoki dute Azkaratek eta Altunak ere, -ek pluralgileaz hitz egin dutenean (ikus gorago eman dudan bere aipua).

Berriz ere, aurreko puntuan aipatutako hizkeraz hizkerako azterketaren beharra agertzen da, Mitxelenak berak, deklinabidearentzako eta konjugazioarentzako bada ere, aitortzen duen bezala (1961[1990: 109]):

No es propio de este lugar, sino más bien de una dialectología vasca, el estudio detenido de las muy diferentes maneras en que se han resuelto los hiatos en la conjugación y sobre todo en la declinación, [...]

Nik dakidala, esku artean dugun gaian lan hori oraindik egin gabe dago; Mitxelenak aipatzen dituen gai horietako baterako, ikus Hualde eta Gaminde (1998).

c) Eutsi diezaiogun oraingoan gorago aipatu dudan bilakaera fonetikoen itsutasunaren ideiari; ekar ditzagun, era berean, zenbait autorek erabilitako erakusleen zerrendak, hirugarren gradu pluralekoenak. Zerrenda hauek Azkaratek eta Altunak (2003: 13-16) txukun bildutakoekin osatu ditut; nire gogora antolatu ditut, sinetsirik datuei begiratzeko modu bat baino gehiago dagoela, eta behin behineko ideia bat iradoki nahian.

1) a.Etxepare: hayec, heyec, hayen, heyen, hayez, hayetaric / hec, hequi, hetan, heçaz b. Leizarraga: haey, hayen / hetan, hetarat, hetarik, hec, heçaz, hequin, hetaco

Ikus daitekeen bezala, formen irregulartasuna agerikoa da, autore bakoitzaren barrenean ere. Ez naute orain haiek eta heiek bezalako aldaerek gehiegi kezkatzen: azalpen fonetiko xinplea dute. Gehiago arduratzen nau haiek eta hek bezalako formak izateak: biak *haek bezalako zerbaitetik eratorri nahi baditugu, zergatik bi emaitza ezberdin? Zergatik batean erabateko asimilazioa, eta bes- 
tean, aldiz, glide epentetikoa? Zergatik bi bilakaera ezberdin? Oihenarten erakusleak hona ekarriz gero, ikusiko genuke, gainera, hec absolutibo eta heiec ergatiboaren artean bereizten duela (Azkarate eta Altuna 2001: 16); badirudi, behin eta berriz iradokitzen hasi naizen bezala, fonetikaz bestelako kontuak daudela jokoan.

Esan bezala, Azkaratek eta Altunak zerrendetan emandako erakusleak nire gogora antolatu ditut, bi talde nagusi osatuz: batetik -ae- bokalismoa dutenak, eta bestetik -e- dutenak. Jakina, antolaketa hori, nirea baita, hemen defenditu nahi dudan proposamenaren araberakoa da, baina espero dut lizentzia metodologiko hau barkatuko zaidala; aipatutako irregulartasun horien azalpen bila egindako sailkapena da hori, ezinbestean axaleko analisi gisa baino ezin aurkez dezakedan azalpena. Oraingoz esan dezadan kasu gramatikalek joera handiagoa dutela -ae- bokalismoa agertzeko, edo hala ematen duela bederen; leku kasuekin, berriz, hetarik, hetako, hetan genituzke nagusi.

Jakina, hau ez da inolaz ere ehuneko ehunean betetzen, eta ez nuke nahi pentsatzea paragrafo horretan esandakoa hipotesi sendo gisa aurkezten dudanik; etorkizuneko azterketetarako ikerbide gisa balio izan dezakeen irudipen soila baino ez da oraingoz. Hipotesi tradizionalak aintzat hartzen ez zuen irudipena, dena den. Beronen bidetik hainbat galdera egiteko aukera dugu, esaterako, ba ote den alderik bokalismoan erakusleak izenordain ala izenaren mugatzaile izan. Halako gogoetak datu enpirikoen test eske ari dira.

Zehaztasun gehiago ezin emanean nagoenez, esan dezadan zein den horren erruduna: falta dugu erakusleen taxonomia zehatza, autorez autorekoa, garaiz garaikoa, eta hizkeraz hizkerakoa; deskripzio lan oinarrizkoena den hori ez dugun bitartean jai dugu irudipen eta usteekin. Eta esan beharrik ez da, lan honek deskripzio behar horretan ez du aurrerapen handirik ekartzen. Baina ez baita hori helburua, kontsola gaitezen ikusirik, gero eta argiago, erakusleen kontu honetan ez garela fonetika hutsarekin ari, gertakari morfologikoak ere tarteko ditugula, edo izan genitzakeela; horiek horrela, erakusleen morfologia diakronikora hurbiltzen ari gara.

Pasa gaitezen orain azken bi puntuetara; biak ideia bakar baten gidaritzapean ekarri ditut hona: pluraleko deklinabidea (ere) erakusle gramatikalizatuz osatua dago.

d) Bada hizkuntzaren beste ezaugarri bat ez doana oso ondo bi bokaleko erakusleekin: deklinabidearen bokalismoa. Izan ere, mendi-etan eta lagun-ek bezalako formak ditugu, eta ez **mendi-aetan edo lagun-aek. Eta zergatik beharko luketen deklinabideko atzizkiek erakusleen forma erakutsi? Ba hain zuzen ere erakusleak dituztelako jatorri. Badakit mendietan bezalako formak azaltzeko hipotesi tradizionalak -eta latineko atzizkiaren alde egiten duela; eta badakit ergatibo pluraleko -ek forma kontrakzio bitartez azaldu izan dela. Baina aurreko lan batean (Manterola 2008a) saiatu naiz erakusten pluraleko deklinabideak zer lotura duen erakusleekin: are gehiago, erabateko identifikazioa aldarrikatu nuen bertan. Horrela, honako bilakaera izango genuke:

2) a. mendi hetan mendietan

b. lagun hek

$>$

$>$ lagunek

Azalpen honek, xinplea izateaz gain, orain arte garbi ez ziren zenbait auzi argitzen du, nik uste. Horien berri xeheagoa Manterola 2008a lanak biltzen du, erabat garatu gabeko hipotesia eta datu bilketa oraindik urria eta sistematizatu gabea akats baldin baditu ere. Hori hala aitortuta, aipa dezadan, dena den, hipotesi horrek azalpen bidean ezartzen duen puntuetako bat, azentuarena alegia. Ekialdeko hizkera zenbaitetan, zuberera kasurako, ergatibo eta genitibo plural diren sintagmetan azentua azken silaban ezartzen da, edo bestela esateko, atzizkiaren gainean; honela: 
3) a. lagunék

b. lagunén

lagunék < lagun hék

lagunén < lagun hén

Azentuaren kokapen hori, azken silabakoa, Mitxelenak (1961[1990: 403]) eta Lafonek (1935) zenbait kontrakzioren bitartez azaltzen dute (ikus Hualde (1997: 79) xehetasunetarako). Baina zer egin azentua azken-azkenaurreko silaban ezartzen duten deklinabide kasuekin?

4) a. mendiétara

mendiétara $<$ mendi hétara

b. mendiétako

mendiétako < mendi hétako

Hauek salbuespen omen dira zubererazko azentueran (Hualde 1997: 80), baina ondo begiratuz gero, batzuek zein besteek, ergatibo, genitibo eta leku kasuek, erakusleek azentua non, haiek ere hortxe, 3) eta 4)ko adibideetan eskuinean adierazten dudan bezala. Beste zenbait hizkeratan ere antzeko azentuera aurkitzen dugu (Lizarraga Elkanokoarenean, adibidez, nahiz eta ikusi dudanaren arabera ez ehuneko ehunean bete). Bada beste hainbat zantzu erakusleak eta deklinabide plurala lotzen dutenak; gorago 1)en eman ditudan erakusleen adibideetan, instrumentalen aldaerak zinez esanguratsuak dira: hezaz, hez, hetaz... Erakusleetan dagoen bariazio berdina, edo horren antzekoa, deklinabidean ere badugu: ez ote da izango berdina ez, baina bera delako?

Ikusten da, argudioetan gehiegi sakondu gabe ere, hipotesi hau gutxienean aski egiantzekoa dela -batere jarri gabe beste hizkuntzetan gertatzen denari begira (Himmelmann 1998); hauei begirada ttiki bat ematea aski da ikusteko ez garela hain bilakaera bitxirik proposatzen ari-. Puntu honek ere bokal bakarreko erakusleen alde egiten du, deus baino gehiago. Ondorengoak ere halaxe egiten du, aurreko honekin estu lotua den neurrian.

e) Erdi Aroko toponimoetan hasperena dugu maiz -eta atzizkia duten lekukotasunetan. Nola azaldu hau, atzizki hori latinekotzat jotzen badugu? Manterolaren (2006, 2008a, 2008b) lanetan azaldu eta arestian aipatu dudan bezala, hobe dugu horietarako erakusle jatorria aldarrikatu. Azazaheta, Erroheta, Beguheta toponimoak deklinatutako izen berranalizatuak baizik ez dira, Azkuek azaldu bezala (1928: 212):

[...] a fuerza de decir arizketara noa voy a los robles, arizketatik nator vengo de los robles, ha quedado arizketa significando robledal [...]

Hartara, naturala da, deklinabidea bera erakusleetatik eratorri denez geroz, garai zaharrenetan hasperena aurkitzea, erakusleen ezaugarri. Eta horixe bera dugu toponimo zahar hauetan. Honenbestez, agerikoa da zein den puntu honetako argudioa: toponimo hauetan ez dugu -haeta forma aurkitzen, -e- bokal bakarrekoa baizik. Jakina, baten batek pentsa lezake ordurako monoptongazioa gertatua zela, baina nola azaldu orduan inguru bereko euskaretan (toponimo hasperendun horiek Arabakoak dira, XII. mendekoak), mende batzuk beranduago, bi bokaldun erakusleak izatea? Badirudi balizko azalpen honek ez lituzkeela arazoak txiki.

\footnotetext{
4. Jakin badakit haien azalgaietako bat lagunak, lagunan (mendebaldea) / lagunek, lagunen (ekialdea) ergatibo eta genitibo pluraleko aldaerak zirela, eta bere hipotesiak horrentzako azalpen sinesgarria ematen zuela. Ikus, halere, 3.3. atalean Eibarko euskara hizpide hartuta horretaz egiten dudan gogoeta.
} 


\section{Hipotesi berria}

Atal honen izenburuak kontrakoa iradoki badezake ere, ez dut lan honetan hainbesteko helburu berehala aurkeztuko dudan (honezkero zeharka agertua) hipotesi berriaren "mirariak" aldarrikatzea. Aurreko atalean dago ikerketa saio honen muina; bertan agertu dudan bezala, erakusleen azterketa axaleko batean zalantza eta gogoetarako bidea irekitzea ez da zaila izan.

Erakusleek badute, beraz, azterketarako potentziala (egia esan, euskal gramatikaren atal gehienen antzera), eta horixe azaleratu nahi nuen. Hori lortu baldin badut, beste euskalari batzuen arreta gai honetara bilduz, nahikoa egin dut. Agian etorkizunean nik a)tik e)ra eman dudan zerrenda luzatu ahal izango da, eta segidan emango dudan hipotesiaz bestelakoak ere aurkeztuko dira. Baina ni, ni naiz, eta oraingoan nire hipotesia, beste hainbaten abiaburu izango den itxaropenean, aurkeztuko dut. Aurkeztuko, edo hobe esan, esplizituki formulatuko dut, eta beronekin harremanean izan daitekeen zenbait datu enpiriko, gertakari eta ideia bertan adieraziko. Hona, bada, hipotesia, hiru puntutan:

-3. graduko erakusleen forma zaharra, jatorrizkoa, bokal bakarrekoa zen (hek, hen, hetan...).

-Forma berriak elementu gramatikalen baten "gehiketaz" osatu ziren.

-Erdialde-mendebaldeko gertaera da hau, ekialdera zabaldu zena.

Lehendabiziko puntuak ez du, seguru aski, azalpen askorik behar: baieztapen aski unibokoa da, eta sinplea. Bigarrenak, aldiz, badu "gehiketa" horren osagaia; gehiketa hori zertan datzan, eta nola gertatu zen azaldu beharko dugu, noizbait. Hirugarrenarekin bete-betean sartzen gara dialektologia diakronikoaren eremuan; honetaz pixka bat arduratzen bagara, eta hala behar luke, euskalki guzietako, egungo eta antzinako, erakusleen deskripzio eta xehekapena suertatuko zaigu egingai. Ahaztu gabe, gainera, dialektoen bilakaera diakronikoaz esandakoak (burutan dut Mitxelenaren (1981) lana, eta baita biltzar honetan aurkeztutako Urgell eta Lakarrarena (2008) ere). Seguru nago erakusleen azterketa xeheak gai honetan zeresana izango duela.

Segidan emango ditudan gogoetek eta ekarriko ditudan datuek aurreko hiru puntu hauen gaineko xehetasunen bidean jarriko gaituzte, beharbada. Gutxienean nire hipotesi honek ekartzen dituen galderak zerrendatzeko balio izango du, nire ustez beste edozein hipotesik ere aintzat hartu beharko lituzkeen galderak.

\subsection{Mendebaldeko erakusle $a$ - morfemadunak}

Has gaitezen mendebaldean aurki daitezkeen erakusle zenbaitekin: amen, aor, aona, aolan... eta gisakoak "intensivos" deitu zituen Azkuek (1905: 1); hasierako a- hori, hala ere, oso antzinako erakusleen osagarri gisa ikusi zuen hau bezalako formetan ere. Mitxelenaren kritikak (1979), aitor duen bezala azterketa xehekatua egin gabe ere, zertxobait argitzen ditu Azkueren hipotesiak dituen arazoak, amen, aor eta halako formak ezin baitira oso zaharrak izan; izatez, aski moderno behar dute izan, testu zaharretan ez direlako ageri (ara emen, ara or, aramen, aror formak ekartzen ditu bere arrazoibidearen sostengu).

Gogoeta interesgarriak ekartzen ditu Mitxelenak mahai gainera, eta seguru nago etorkizunean berorietan argitutakoetatik, eta baita isilpean azaldu gabekoetatik ere abiatuko dela hainbat punturen azalpena. Oraingoz, baina, adibide hauek nire eztabaida orokorrean (edo, bestela esan, erakusleez ari den edozeinetan) sartu behar direla gogoratzeko baizik ez ditut hemen aipatu, oroigarri. Hauetako hasierako a- hori modernoa izanda ere, Mitxelenak dioen bezala, ikusi beharko 
bailitzateke euskararen bilakabide diakronikoan zenbateraino gertatu diren halako gehitze eta berregituratze morfologikoak (ez, hortaz, fonetika hutsezkoak) erakusleetan. Eta jakina, erabat sinesten dut hara, ecce "aurkeztaile" horretaz aparteko bestelako azalpenek ere bere tokia izan beharko dutela (ikus Mitxelena 1979 [1987: 448] eta Altube 1934 [1969: 205]), halakoren batean eta ikerketak aurrera egiten badu, gure aukeren artean.

Ataltxo hau bukatzeko, adieraz dezadan, norbaitek jakin-mina balu, zein diren orain burutan ditudan azalpen aukerak; bistan da, aukera hauek oraingoz etorkizun diren hipotesien aitzindari baizik ez dira, oinarri handirik gabekoak, eta zerrenda itxia osatzen ez dutenak: batetik, aek bezalakoetan izan al liteke (h)a erakuslea + hek berreraiki behar izatea? Bigarren aukera gisa, izan al liteke a "beste zerbait" + hek izatea hor? Eta hirugarrenik, izan al liteke erakusle oinarriko beste elementuren bat (hara...) + hek edo izatea? Egin dudan hiru aukeren formalizazio kaxkarrak argi uzten du etorkizuneko ikerketak behar duen sakontze lana.

\subsection{Hizkuntza erromantzeetako 3. graduko erakusleak}

Gauza ezaguna da latinaren erakusle sistema hiru gradukoa zela; hurbiltasunaren eta urruntasunaren araberako graduak ziren hauek. Hic, iste eta ille ziren (ez ditut femeninozko eta neutroak jarriko, aringarri), nahi izatera euskarazko hau, hori eta hura erakusleen ondoan jar daitezkeenak. Gauza jakina da, halaber, espainola bezalako hizkuntza erromantze batek ere hiru gradukoa duela erakusle sistema, baina ezberdintasun ttiki zenbaitekin: hic-en oinordeko lexiko zuzena ez da erabiltzen lehen graduko erakusle gisa, haren tokia iste-k (espainolezko este) hartu duelarik.

Gatozen guretzako interesgarria den kasura. Era berean, eta gaztelaniazko erakusle sistema osoaren bilakabide diakronikoa azaltzen hasi gabe, gaztelaniazko hirugarren graduko aquel ere ez da latinezko ille horren oinordeko zuzen-zuzena. Kasu honetan, ordea, berregituratze morfologiko baten aurrean gaude, izan ere aquel horren parte baita latindar garaiko ille. Parte bai, baina ez aski egungo aquel formaren jatorrizko morfologia azaltzeko. Nonbait, Erdi Aroko garai ez oso dokumentatuetan, ille erakuslea, artikulurako bidea ere hartua zuena, bere erakusle izaera indartu beharrean sentitu zen; edo garaiko hiztunek hala sentitu zuten, bederen; edo hizkuntzak, besterik gabe, bide hori hartu zuen. Indartu, nola baina?

Azalpen tradizionalaren arabera, *accu "gehitu" zen jatorrizko ille erakuslearen aurrean; jakina, "gehitu" izendapena ez da inolaz ere zinez gertatu zenaren adierazgarri (hitzak inoiz errealitateen adierazgarri izan daitezkeen neurrian), bere atzean hamaika gertaera eta xehetasun ezkutatzen baititu. Ez naiz orain zidor horietan barrena abiatuko, oraingoz nahikoa baitut, nik uste, berregituratze morfologiko horren berri ematea, hain hurbileko, bertako batzuetan, den hizkuntzan. *Accu latinezko ecce aurkeztailearen pareko edo ondorengotzat jo ohi da eta, beraz, *accu + ille > aquel bilakaera arestian Mitxelenaren hitzak baliatuz euskaran gertaera modernotzat jo dugun hara hura, hara hor bilakaeratik aski hurbilekoa dugu. Ba ote, euskaran ere, ezkutupeko Erdi Aro hartan, horrelako, edo antzeko bilakaerarik? Inguruko hizkuntza erromantzeen eredura, beharbada? Edo bestelako kontaktu norabideetan pentsa ote genezake?

Kontaktuak eragindako bilakaeren auzian inolako erabaki jakinik hartu gabe (auzi horretan erabakirik hartu behar den esatera ausartu gabe ere), erromantzearen 3. graduko erakusle honen bilakaera diakronikoa ekarri dut hona. Berregituratze morfologikoaren aukera da, beraz, ekarri dudana, ez hainbeste proposatu nahi nukeen azalpen bakar gisa, baizik eta balizko hipotesien taldean (fonetikazkoekin batera) berak ere lekua izan dezan.

Azken ohartxo bat, bestelako hizkuntzak aipagai ditugun azpiatal honetan: beste ataletan 
euskararen baitako datuak xeheki aztertzea falta dugula aitortu(ko) dugun bezala, hemen ezinbesteko aitorpen gehigarri bat dator harira: munduko hizkuntzetan erakusleen bilakaera eta berregituratzea nola gertatzen den ez dut oraindik ondo ezarria, euskararen kasurako balizko paralelo bila lagunduko ligukeen lana. Hau ere, ikerketa oinarri sendoz hornitu nahi badugu, saihestezina dugun eginbeharra da; barka bertan behar bezalako argibiderik ez badut ematen.

\subsection{Mendebaldeko genitibo pluralak eta superlatiboak}

Pluraleko erakusle urrunen osaerarekin zerikusia izan dezakeelakoan, hona aipatu nahi nukeen hirugarren kontu bat: mendebaldeko hizkeretan, antzinako lekukotasunetan bederen, baditugu ilaen arterean "de entre los muertos" bezalako genitibo pluralak; badira, halaber, andiaen bezalako superlatiboak. Zuzenean burura datorkidan galdera, bistan dena, superlatibo eta genitiboaren arteko loturarena da eta, halaber, haien osaerarena. Gorago, lehenengo ataleko d) azpi-puntuan, deklinabideko genitibo pluralaren forma erakusle urruneko genitibo pluralarekin lotu dugu. Superlatiboa bera ere genitibo pluraleko deklinabidearekin lotu -hobe esan, identifikatu- izan da literaturan; ilaen bezalako formak il-aen gisa analizatu nahi izatera (hori ere ez baitago behar bezala zehaztua), eta andiaen forman ere andi-aen ikusi nahi badugu, baliteke forma guztiek erakusleetako aen horrekin gutxieneko zerikusia izatea. ${ }^{5}$

Jakina, berriz ere, forma hauek guztiak (deklinabide pluralekoa, superlatiboarena eta erakuslearena) fonetikarekin ere azal daitezke, nahi izanez gero -nahia dugunean, edozer azal dezakegu edozerekin; gure lana azalpen ezberdinak egiantzekotasunaren arabera egoki mailakatzea da, baina-. Sintomatiko xamarra da, dena den, hipotesi tradizionalak galdera hauek ez egitea; eta horretan datza, halakorik badu, honako lan honen balioa.

Adibide hauek guztiak, erakusle zein deklinabide, batera lantzeko deia da hau; baina, honezkero irakurleak sumatuko zuen bezala, egin beharreko lana egin gabe dago: aukera hau, eta aurkez daitezkeen beste guztiak, datuen argipean piztu ala itzaliko dira. Beste behin ere, datuen bilketa sistematiko baten zain beharko dugu egon.

\section{Zenbait gogoeta, azterketa sakonago batek aintzat hartu beharko dituena ${ }^{6}$}

Lehenengo atalean hipotesi tradizionalaren hutsuneetan, edo azaldu gabekoetan sakontzen saiatu naiz, bigarrenean bestelako hipotesi bat proposatzeko. Bigarren atalean berean, hipotesi berri horrekin lotura izan lezaketen hiru kontu aurkeztu ditut; hirurak, denak izan dira erakusleen morfologiari estu-estuan zegozkionak. Eta horietatik, argitu gabeko horietatik (gogoan izan datuen azterketa sistematikoaren falta), urrunago edo, beharbada, maila orokorragoko proposamenetara, gogoetetara abiatuko gara orain.

\subsection{Erakusleen (balizko) berregituratze morfologikoaren garaiaz; deklinabide pluralarena.}

Deklinabidea, pluralekoa ere bai, erabat erakusleen menpeko gisa aurkeztu dugu. Galdera berehalakoa da: deklinabidean ez bada, itxura guztien arabera, erakusleen hasierako $a$ - horren zantzurik batere aurkitzen, noizkoa da erakusleetan guk berregituratze morfologikotzat jo dugun bilakaera

5. Mitxelenak aukera gisa iradokitzen duen bezala (1961 [1991: 117-118]) Goiahen 'summus' balitz, izan al liteke ahen hori, goi + ahen analizatuta, erakusle genitibo plural berregituratutako horietako bat? Oraindik hasperena gordetzen duena? Adibide bakarrarekin ezin deus erabaki. 
hori? Honek, jakina, bere baitan inplizitu daraman galdera pluraleko deklinabidearen beraren bilakaera garaiarena da.

Zuzenean erantzun gabe ekar dezadan hona auzi honetan gogoetarako bide eman dezakeen zenbait kontu:

.Esan izan da pluraleko deklinabidea berantiarragoa dela singularrekoa baino; azentueraren aldetik, hortxe ditugu Hualderen lanak $(1997,2005)$ argudio horren ildoari segitzen diotenak, eta baita, oztopoak oztopo, klasikoagoa den Mitxelenarena (1981), aldapea eta aldapaak (aldapaan ere bai) bezalako adibideak aintzat hartzen dituena. Lan hauek guztiek beti jo izan dute, modu erlatiboan bada ere, singularrekoekiko, pluralekoen berantiartasuna aitortzera; batzuek azentueraren gorabeheren bidetik, Hualderenek, besteek, Mitxelenarenek, morfologia soilaren bidetik nagusiki. Pentsabide honen ildoan sartu beharko da erakusleez esan dugun guztia, gure proposamena tradizioan txertatuko badugu, ideia zaharrekin zubia eginez.

.Hualderen azentuak eta Mitxelenaren gogoetak pluraleko deklinabidearen "modernotasunaz" hitz egiten digutenean, zertaz ari dira zehazki? Deklinabidea bera, pluralekoa bederen, oso gramatikalizatua ez zegoela adierazi nahi dute; hots, pluraleko markak ez zirela izen sintagmari erabat modu estuan lotuak. Ilaen, andiaen... bezalako formek horren alde egin lezakete, seguru aski, kontuak behar bezala zehaztuz gero. Deklinabidea bera erabat zehaztua, nolabait "eihartua" ez baldin bazegoen, eta bere atzizkiak oraindik erakusleekin eurekin identifikatu baldin bazitezkeen, baliteke erakusle formak berritu zirenean horiek, erakusle forma berri horiek, guk morfologikoki berregituratutzat jo ditugun horiek, sartu izana deklinabidean. Hala izango genituzke ilaen genitibo pluralak, edo andiaen superlatiboak.

Laburbilduz, deklinabide pluralaren erabateko fusioa berantiarra da (azentu patroi beregainak lekuko, ekialdean zein mendebaldean), eta horrek ahalbidetu zuen berriago eta berregituratutakoak diren erakusleak deklinabidean sartzea. Horra bada gertaera hauek, erakusleena baina baita deklinabidearena berarena ere, denboran kokatzeko erabil ditzakegun pista erlatiboak.

- Artikulu definituaren gramatikalizazioa, azken batean urruneko erakusle singular absolutiboaren gramatikalizazioa dena, Erdi Arokotzat jo izan da, inguruko hizkuntzetako kideko gertaerarekin lotuz. Bestelako erakusle hauen gramatikalizazioa ere ikuspegi beretik ikusi nahi izanez gero, eta balizko kontaktu egoera horrek berak ematen digun kronologiari erreparatuta, noizkoak ditugu gertaerok? Hots, noizkoa da erromantzeetako erakusleen gramatikalizazioa? Honek ere denboran ainguratze bat eskaintzen digu, beti ere kontaktu-egoera aintzat hartu nahi, edo datuek horretaratuta, behar badugu.

\subsection{Erakusleen osaeraz: plural markaz}

Itzul gaitezen, gogoeta "informatibo" gisa, Azkarate eta Altunaren aipu hartara, lehen atalean eman dugun hartara. Bertan -toki ttikia hartzen duenez berrekar dezadan aipua- plural marka gisa hartzen da -ek:

Pluraleko formez den bezanbatean, euskalkirik gehienetan, jakina den bezala, singularreko absolutiboan oinarritzen dira eta horri gehitzen -ek plural marka: hau / hauek; hori / horiek; ha (hura) / haek > haiek (>heiek > hek).

Euskararen gramatikan plural marka bat zer den, egun edo antzina, ez dute inon azaltzen. Era berean, pluraltasunaren kontzeptuak berak, hiru etxe esaten duen hizkuntza batean -eta ez tres casaS, trois maisonS edo three houseS- ez da oso argi zer toki zuen, duen. Seguru aski Lafonen 
(1954) eta Irigoienen (1985) lanak lagungarri izango dira arazo horretan murgiltzeko, baina ez dut hemengo eginkizun horretaz aritzea.

Hizkuntzaren izaerari modu orokorrean eragiten dion auzi honen aurrean, dena den, helburu xumeagoetan aritu gintezke, beharbada: zer da -ek hori? Hara... deklinabidean ergatibo pluralarentzako erakusle jatorria proposatu dugu, lehendabiziko ataleko d) puntuan esan bezala. Izan liteke erakusleetan ere halako zerbait gertatu izana? Ez nuke nahi datozen lerrootan botako ditudan ideiak eta ekarriko ditudan datuak galdera honen erantzun erabatekotzat hartzea; baliteke, dena den, ideia, datu eta datuak ikusteko modu horrekin arazoa bera aberastea, etorkizunean aukera gisa baztertzeko bada ere.

Eman dezagun momentu batez hauek, horiek, haek < hau + hek, hori + hek, ha + hek bilakaera dugula. Zerekin sustenga dezakegu proposamen hau? Euskarazko datu historikoekin badirudi ezetz. Baina jo dezagun estotro, esotro < esto + otro, eso + otro bezalakoetara; badakit, hauek singularrekoak dira, ez pluraleko hauek, horiek eta haek bezala. Onar ditzagun behin-behinean datu horiek ondoren datorren argudioan lagungarri izango direlakoan.

Ekar ditzagun orain vosotros eta nosotros izenordainak, zuek eta lekukotua den guek horren parean jarriko ditudanak; eztabaida berari legozkiokeen euskarazko datuen zerrenda luzatzen dugu horrela, nik uste. Azter ditzagun orain zuek eta guek zu + hek eta gu + hek balira bezala; gauza jakina da antzinako gaztelaniako (latinezko) izenordainak nos eta vos zirela, eta izenordain berrietarako jauzia aski "modernoa" dela (XI-XII. mendeko Cantar del Mio Cid-en nos eta vos erabiltzen dira). Vos bera, jatorriz bigarren pertsona plurala, errespetuzko bigarren pertsona singular gisa erabili izan da, eta erabilera hori geratu da, eihartuta, Hego Ameriketako zenbait hizkeratan. Euskaraz horixe bera dugu gaur egun, hi izenordainaren kaltetan; plural balioa gordetzen duten zu zenbait ere badugu euskal testu arkaikoetan. Euskarazko zuek (eta guek) formak ere, beraz, ezin oso antzinako izan. Gaztelaniazkoen garaikide? Bi hizkuntzek bilakaera horretan hainbeste antzekotasun agertuta, ez dirudi zentzugabea horrela pentsatzea.

Gatozen formulazio zehatzagoetara: nosotros eta vosotros izenordainen bilakaera ezaguna, euskarazko zuek izenordainarenarekin hain erraz paraleloan jar daitekeena, bi morfema beregainen, nos eta otros, "batuketatik" eratorri baldin bada, zergatik ez pentsatu antzeko zerbait euskararentzako? Euskaraz ere bi morfema beregain ditugu egungo zuek (eta antzina lekukotua dugun guek ${ }^{7}$ ) horren osaeraren jatorrian: $z u+h e k$.

Gaztelaniaren eta euskararen artean ezarri dugun paralelo honen arabera -ikerketaren puntu honetan aski ad hoc suerta litekeena- irudi luke otro(s) horren funtzioa arestian aipatutako hek horienekin parekatzen dela. Horietara itzulita, ezin al liteke laukia osatu? vosotros - zuek eta estotro - X laukia inkognitaren ordez hauek bezalako erakusleak jarrita ezin al da osatu? Hauxe da hemen plazaratu nahi dudan aukera.

Datuak honela antolatuta, eta berebizikoa duen eta falta duen azterketa sakonik gabe, aukera hau beste hainbat bezain egiantzeko izan daiteke. Azalpen bidean jarriko genituzkeen auzien ar-

6. Esanguratsua izan liteke, bide batez, Erdi Aroko guek hura aditz trantsitibo baten subjektu izatea (guec ajutu ez dugu da esaldia). Datu bakarrarekin, dena den, ezin gauza handirik egin. Irakur Irigoienen lana (1975: 170) argibide gehiagorako; esan dezadan bide batez, erreferentziako orrialde horretan nik hemen aztergai izan ditudan hainbat kontu aipatuak ditu berak jadanik. Artean irakurri gabea nuen Irigoienen lana, barka beraz kontuak errepikatua. 
tean, gainera, -ek pluralgile misteriotsuarena dugu bat.

\subsection{Ergatibitateaz ohar bat}

Orain arteko azalpen bideak dakarren galdera bat plazaratu nahi nuke atal honetan: zein ote zen ergatibitatearen rola, ikusirik erakusle pluraletan (hauek, horiek, haiek) ez dela bereizten, hain zuzen -ek pluralgilea hartu duen izenordainean bezala (zuek ergatiboa eta absolutiboa)? -ek hartu ez duen izenordainean, aldiz, ez da halakorik gertatzen ( $g u$ absolutiboa eta guk ergatiboa). Gogoan izan behar dugu deklinabidean hek hau ergatibo kasu pluralarekin lotu dudala: ba ote du honek zer esanik oraintxe esandako honetaz? Galderak egiten hasita, miatu liteke gaztelaniazko vosotros eta nosotros izenordainen bilakaera zehatza zein izan zen, aztertuz subjektu posizioan hasi ote ziren, ala objektuzkoan, aditz iragankorrekin ala iragangaitzekin.

Deklinabidea ere, berriz, aipagai dudan honetan, galdera berehalakoa da, aurreko hipotesiak argitzen (omen) zuen eta gurean azalpenik gabe geratzen denaz: nola azaldu ergatibo eta genitibo pluralean dugun banaketa dialektala, -ak/-an formaren eta -ek/-en formaren artekoa? Gogoan izan Mitxelena eta Lafonen irtenbidea *lagun-ag-en eta *lagun-ag-ek bezalako protoformak proposatzea zela. Hona nire gogoetak, oso landuak ez badira ere:

-Ergatiboari gagozkiolarik, pentsa ote liteke, Mitxelena eta Lafonen eredu estrukturalistari muzin eginez, mendebaldean ez zela -(e)k ergatiboaren bilakaerarik izan eta absolutiboarentzako balio zuen -ak morfemarekin aski izan zela? Ergatiboarentzako hala balitz, zer egin genitiboarekin? Honek ez baitu ergatiboak absolutiboarekin duen "aurkaririk".

-Mendebaldeko -aen formadun genitibo plural eta superlatiboak aintzat hartuta, bokalismo dialektalen gorabehera horiek berdin azal daitezke, Lafonen eta Mitxelenaren hipotesian bezalaxe. Baina, oraingoan, zer egin ergatibo plurala azaltzeko? Ez baita -aek bezalako formarik lekukotua deklinabideko ergatibo pluralean, nik dakidala. Honetan, berriz ere, badirudi ergatibo eta genitibo pluralak ez doazela batera.

-Zer egin Eibarko euskara bezalako kasuekin, genitibo pluralak eta ergatibo pluralak bokalismo ezberdina erakusten dutenak? ibarrak, alabak (ergatibo plurala) eta ibarren, alaben (genitibo plurala) ditugu horietan (Sarasua, Agirrebeña eta Zenarruzabeitia 2005: 152-153). Aurreko bi gogoetetan hipotesiak ziren bitartean, genitibo eta ergatibo pluralaren batasuna zalantzan jartzen zutenak, hemen datu dialektal modernoak ditugu, norabide berean eraman lezaketenak. Hipotesi tradizionalak ez du deus zehatzik esaten honetaz.

Beste behin ere bistan dena zera da: euskalkietako deklinabide moldeei, forma jakinei hobeto begiratu behar diegu. Berriz ere, egin gabeko lan zehatza falta da, euskalkiak, eta eskura ditugun neurrian, testuak, banan-banan aztertuko dituena; ahal bada, hemen zerrendan eman ditugun arazoak gogoan hartuta.

\subsection{Genitibo pluralaz. Iberikoa eta euskara.}

Ez naiz ni, berehalakoan, besterik gabean, hipotesi eusko-iberistaren alde egingo lukeen horietarikoa, baina bada kontu bat bitxi egin zaidana. Gauza ezaguna da (ikus Vallejo (1946, 1950) argibideetarako) iberierazko txanpon batzuetan -en itxurako morfema batzuk genitibo plural gisa identifikatu izan dituztela; jakina, berehala ekarri zuen horrek euskararekiko konparazioa. Era berean, arreta jarri zitzaion iberierazko balizko genitibo plural horien beste aldaera bati, -sken formadunari. Honek, jakina, euskaratik aldentzen du.

Hemen dator, baina, aipagarri gertatzen zaidan kontua: beste nonbait (Manterola 2008a) adierazi dut azken hitza hatz + hen itxurako superlatiboa izan daitekeela; azken hitza superlatibotzat 
jotzea ez da ideia berria (Azkue 1923: 28, Michelena 1961: 219), eta -hen hasperendun superlatiboa (erakusle genitibo plurala) lekukotua dugu, nire ustez, Erdi Aroan (Arbelgoihen, Manterola 2006: 674). Azken hitzeko -ken atzizkiaren forma kontsonante ahoskabeduna aurretik duen testuinguru fonetikoaren araberakoa dela uste dut, "ezkerrean" duen frikariak baldintzatua; berdin-berdin proposatu da -eta/-keta alternantziarentzako (Michelena 1971).

Nire galdera zera da: iberieraz agertzen omen diren -sken itxurako genitibo plural horiek, ez al dira antzeko baldintzatze fonetiko baten lekuko? Zalantzaren adarretan zintzilik utzi nahi nukeen gogoeta da hau, beste behin ere euskararen eta iberieraren arteko fonetikaren aldetiko kointzidentzia salatuko lukeena. Tartean, halere, arazoak, arazo handiak, gainditu beharko lituzke aukera honek: lekukotasun iberiko horien garaiaren -erromatarren etorreraren aurrekoak edo garaitsukoak diraeta euskararen gertaerentzako proposatzen dugun kronologiaren artean dagoen jauziarena, besteak beste. Ohar anekdotiko gisa gera bedi kontua, beraz, oraingoz.

\section{4.- Bukatzeko}

Lanean zehar etengabe aipatu izan da testuen eta aldaera dialektalen azterketa xehekatuaren beharra, eta horiek gabe edozein hipotei kamuts geratzen dela; dena den, nago aurkeztu dudan hipotesi nagusia eta bertatik adarkatutako azpi-hipotesiak agertzearen eginahala beharrezkoa dela, etorkizunean baztertzekoak izango balira ere.

Azken gogoeta solte bezala, hala ere, erantzunik jasoko ez duen zenbait galdera plazaratu nahi nuke, gai honen inguruko ikerketek euskal gramatikagintza diakronikoan izan lezaketen interesaren adierazgarri:

-Hauk bezalako formak (hauek formen ondoan) -e- bokalaren lenizioaren ondorengo ikusi behar ditugu? Ala inoiz halakorik izan gabekoak izan al daitezke? Tradiziozko erantzunak lehen aukeraren alde egingo luke, baina nahiago nuke datuen sostengupean berretsiko bagenu.

-Pluraleko *-aga (Mitxelena 1971) zer da? Erakusle gramatikalizatua ote hau ere? Horretaraxe zuzenduko litzateke nire lehen susmoa (halaxe adierazten du Hualdek ere (2008: 210)). Baina argitu gabeko kontu zenbait ere bada, nik uste, forma horietan. Bokalismoarena izan daiteke bat, eta ikus, gainera, Mitxelenak egiten duen oharra (1969 [1987: 113]).

-Euskara batu zaharraren hipotesia gogoan edukita (Michelena 1981), zer eskaintzen digu erakusleak berreraikitzeko aukera berri honek? Zer dugu esateko dialektologia diakronikoaz? Mendebaldeko formak izan litezke berritzaile gramatikaren atal honetan; kontaktu gune handiagoa baitzen orduko euskararen mendebaldea? Beharbada beste zenbait lanetako datuak pilatuta norabide horretan arakatzen segi genezake (Urgell 2006: 941).

Zein da hemen aztertu ditugun adibideetan fonetikaren eta morfologiaren, nor bere aldetik eta biak elkarreragintzan, erantzukizuna?

-Erakusleen hasierako herskari, hasperen edo dena delakoaren gaineko galderak ere berehalakoan datoz ikerketaren harian. Zein zen bere jatorrizko izaera fonikoa? Eta inportanteagoa hemen agertu dudan gogoeta ildoan: nola eragin zuen nire ustez berregituratze morfologikoa izan zen horrek ekialdeko erakusleen (hots, kontsonantea, dela hasperena dela herskaria, gordetzen dutenen) osaeran? Seguru aski ez zen, berregituratzearen hau, euskalki guzietan prozesu berdina izan: haietako batzuetan baliabide diskurtsibo jakin zenbaitek gidatua izan ote zen, beste zenbaitetan euskalkien arteko interferentzia gisa zabaldu zen bitartean?

- Eta, azkenik, aldarri bat, lan honena eta nire besterena: deklinabidearen eta erakusleen aldaerak batera aztertzearen garrantzia aitortu behar da; hasieran 1)en eman ditugun adibideen artean seguru aski esanguratsuena, aldaera gehien eta handienak erakusten dituelako, instrumentalarena 
izan daiteke: haiez, hetaz, hezaz eta deklinabidean, -ez, -etaz, -ezaz. Ikus halakoetarako Altuberen oharra (1934[1969: 177]) eta Eguskitzarena (1969: 389).

Horra bada honenbestez esan beharrekoak. Txarrenean, lehenago zein bere kaxa aztertzen ziren datuak batera bildu ditut hemen, ustez eta hala eginez proposamen integralagoak eta asegarriagoak proposatzera iritsiko garela inoiz. Barkatuko zait erantzun baino galdera gehiagorekin etorri izana. Agian oholtza gainera ekarritako galdera berriekin erantzun gabe utzitakoak gainditu ditut; hurrengoan, oraingoaren aitzakian, galdera berri gehiagorekin etorri ahal izateko.

\section{OHARRA}

Ohar ttiki bat artikulu honetan azaldutako ideiaren sorburuaz, proposamen honetara nolatan etorri naizen argituko duelakoan: ez da berezko indarrez sortutako gogoeta ildoa, erakusleak nola berreraiki ote litezkeen galdetuta sortutakoa. Lehendabiziko ataleko d) eta e) azpiataletan emandako gogoetak ditu iturri; erakusleak berreraikitzeko beharra, hortaz, ez datorkit zuzenean erakusleenganako ardura jakin batetik, auzi orokorrago batetik baizik: deklinabidearen osaerarenetik.

Nago, dena den, horrek berak indar handiagoa ematen diola erakusleen berreraiketari, hasieran arazo independente zirenetatik abiatzeak ematen duen ziurtasun metodologikoa bestelako susmo eta mesfidantzen lasaigarri izaten baita.

Era berean, hemen aurkeztutakoak 2007 ko ekaineko jardunaldi batzuetan Beñat Oihartzabalek egindako galdera sorta bati erantzun nahian emandakoak dira; bera izan da, hortaz, honakoaren akuilu. Orduko hartan erantzun zehatzik gabe geratu zen; oraingoan ere ezin esan erabat aurkakoa gertatu denik, baina ahalegina eskertuko dit beharbada. Hona bada nire esker ona, bere galderen zorrotzak ikertzailearengan eragiten duen aztoramenaren erakusgarri.

\section{Bibliografia}

Ahotsak.com. 2007. Oitz. Bederatzi urterekin tiragomarekin ehizean. [http://www.ahotsak.com/ oitz/pasartea/18543, 2009-3-8(e)an ikusia]

Altube, Seber. 1934. Observaciones al tratado de "Morfología Vasca" de Don R. M. de Azkue. Morfología Vasca III. [Berrargitalpena: 1969]

Altuna, Patxi eta Azkarate, Miren. 2001. Euskal morfologiaren historia. Donostia: Elkarlanean.

Azkue, Resurrección María. 1905-1906. Diccionario vasco-español-francés. Bilbao: La Gran Enciclopedia Vasca. [Berrargitalpena: 1969]

Azkue, Resurrección María. 1923. Morfología Vasca. Bilbao: La Gran Enciclopedia Vasca. [Berrargitalpena: 1969]

Azkue, Resurrección María. 1928. El artículo y la epéntesis en la toponimia. Euskera 9, 212-217.

de Rijk, Rudolf P. G. 1981. Euskal morfologiaren zenbait gorabehera. Euskal linguistika eta literatura: bide berriak, 83-101.

Eguskitza. 1969. Observaciones a algunos puntos de la Morfología Vasca del señor Azkue. Morfología Vasca III, 389-394.

Himmelmann, Nikolaus P. 1998. Regularity in irregularity: Article use in adpositional phrases. Linguistic Typology 2, 315-353.

Hualde, José Ignacio. 1997. Euskararen azentuerak. Donostia, Bilbo: Gipuzkoako Foru Aldundia, EHU.

Hualde, José Ignacio. 2005. Azentua eta etimologia. Nerekin yaio nun. Txillardegiri omenaldia, Etxeberria, Pilartxo and Knörr, Henrike, Iker 17, 297-303. 
Hualde, José Ignacio. 2008. Acentuación y cronología relativa en la lengua vasca. Oihenart 23, 201-219.

Hualde, José Ignacio eta Gaminde, Iñaki. 1998. Vowel interaction in Basque: a nearly exhaustive catalogue. Studies in the Linguistic Sciences 28(1), 41-77.

Irigoien, Alfonso. 1985. Euskarazko izen sintagma mugatzailerik gabekoez. Euskera 30, 129-139.

Irigoyen, Alfonso. 1975. Done Miliaga Kukullakoa eta euskara. Euskera 20, 161-186.

Irigoyen, Alfonso. 1978. Erakusleez. Euskera 24, 713-735.

Irigoyen, Alfonso. 1981. Haur hola zirola. Elementos deícticos en lengua vasca.

Lafon, René. 1935. Observations sur la place de l'accent dans quelques formes basques des parlers souletins. Mélanges de littérature, d'histoire et de philologie offerts à Paul Laumonier, 635-643. [Berrargitalpena: Lafon 1999: 697-703]

Lafon, René. 1954. Le nombre dans la déclinaison basque. Via Domitia 1, 111-121. [Berrargitalpena: Lafon 1999: 209-217]

Manterola, Julen. 2006. - a euskal artikulua definituaren gainean zenbait ohar. Studies in Basque and Historical Linguistics in Memory of R. L. Trask, Lakarra, Joseba Andoni and Hualde, José Ignacio, Anuario del Seminario de Filología Vasca "Julio de Urquijo" XL, 651-676.

Manterola, Julen. 2008a. Is Basque an agglutinative language? A proposal for the diachrony of nominal morphology. TINTA, Research Journal of Hispanic and Lusophone Studies.

Manterola, Julen. 2008b. Euskarazko artikuluak Erdi Aroko agiri bilduma batean. Oihenart 23.

Michelena, Luis. 961. Fonética histórica vasca. Donostia: Gipuzkoako Foru Aldundia. [Berrargitalpena: 1990]

Michelena, Luis. 1969. Notas lingüísticas a "Colección diplomática de Irache". Fontes Linguae Vasconum I, 1-59. [Berrargitalpena: Michelena 1987: 87-140]

Michelena, Luis. 1971. Toponimia, léxico y gramática. Fontes Linguae Vasconum 9, 241-267. [Berrargitalpena: Michelena 1987: 141-167]

Michelena, Luis. 1979. Miscelánea filológica vasca IV. Fontes Linguae Vasconum 33, 307-406. [Berrargitalpena: Michelena 1987: 435-463]

Michelena, Luis. 1981. Lengua común y dialectos vascos. Anuario del Seminario de Filología Vasca "Julio de Urquijo" XV, 291-313. [Berrargitalpena: Michelena 1987: 35-55]

Michelena, Luis. 1987. Palabras y textos. Bilbo: EHU.

Múgica, Serapio. 1908. El vascuence en los archivos municipales de Guipúzcoa. Revista Internacional de Estudios Vascos 2(5), 725-733

Sarasua, Asier, Agirrebeña, Aintzane eta Zenarruzabeitia, Leire. 2005. Eibarko euskara. Gure hizketaren doinu eta berbak. Eibar: Eibarko Udala.

Urgell, Blanka. 2006. Para la historia del sustantivo verbal en vasco. Studies in Basque and Historical Linguistics in Memory of R. L. Trask, Lakarra, Joseba Andoni and Hualde, José Ignacio, Anuario del Seminario de Filología Vasca "Julio de Urquijo" XL, 921-948.

Urgell, Blanka eta Lakarra, Joseba Andoni. 2008. Hausturak nonahi, noiznahi, zenbatnahi: gogoetak euskal dialektologia diakronikoaz. Aldaketak, aldaerak, bariazioak euskaran eta euskal testugintzan mintegian aurkeztutako lana, Baiona, 2008-12-13.

Vallejo, José. 1946. En torno a un vieja moneda ibérica. Emerita 14, 242-258.

Vallejo, José. 1950. Sobre ibérico “-(s)ken” y “-en”. Emerita 18, 215-220. 